\title{
THE EFFECTS OF ORGANIZATIONAL CULTURE ON EMPLOYEE PERFORMANCE IN SUMEDANG SELATAN DISTRICT OFFICE SUMEDANG REGENCY
}

\author{
Fepi Febianti $^{a *}$, Teddy Marliadi Nurwan ${ }^{a)}$ \\ ${ }^{a)}$ Sekolah Tinggi Ilmu Administrasi Sebelas April, Sumedang, Indonesia \\ ${ }^{*}$ Corresponding Author: fepifebianti@gmail.com
}

Article history: received 08 December 2020; revised 15 December 2020; accepted 26 December 2020

\begin{abstract}
The core of the problem in this study is to determine the effects of organizational culture on employee performance in Sumedang Selatan District Office, Sumedang Regency. This study aims to determine the implementation, correlation, and effects of organizational culture on employee performance in Sumedang Selatan District Office, Sumedang Regency. This study used a survey method. Data collection techniques used were observation, interviews, questionnaires, and data processing related to the problems studied namely organizational culture and employee performance. The analysis technique used is a simple regression analysis, correlation test, coefficient of determination, and hypothesis testing. The research sample used as many as 46 people, namely all civil servants in Sumedang Selatan District Office. The results of quantitative calculations were obtained based on the value of the Pearson correlation (r). It is known that the $r$ value for the effects of organizational culture $(X)$ on employee performance $(Y)$ is $0.713>r$ table 0.290. So it can be concluded that there is a correlation between the organizational culture (X) to employee performance (Y).
\end{abstract}

Keywords: organizational culture; employee performance

\section{INTRODUCTION}

An organization is established with several goals that become common ideals. These ideals must be supported by various factors. All factors and aspects that can support the achievement of the goals start from how the organization manages the resources contained therein. The organization consists of several people who have a role and contribution that is useful in achieving the goals of the organization. The success or failure of an organization can be seen from the achievement of the initial goals that have been arranged in the vision and mission, which can be seen from how the performance of each individual in the organization. Performance is an assessment of how the role and contribution of a person (in this case human resources in an organization) that affects the level of organization's development.

Performance is not something that presents suddenly. The good or bad performance of a person is largely determined by several factors, which can be internal or external. This affects how a person works to create a good performance which will certainly support the achievement of the organization's goals. One of the other factors that affect a person's performance at work is organizational culture. Organizational culture can be defined as a culture that is created in an organization based on rules or habits that have emerged from generation to generation. So that it eventually becomes a culture or habit that is considered normal in an organization.

Another factor that can affect a person's performance is a reward \& punishment policy. Reward \& punishment policy is one of the policies imposed by an organization that states what should be done and what should not be done. This policy talks about giving appreciation for those who have a good work ethic, as well as giving penalties for violators who violate the rules. Reward \& punishment policy has a very vital character, so that in its implementation it must be fair and appropriate.

Organizational culture is the norms, values, assumptions, beliefs, philosophy, organizational habits, and so on (the content of organizational culture) developed for a long time by the founders, leaders, and members of the organization which are socialized and taught to new members and applied in activities organization so that it affects the mindset, attitudes and behavior of organizational members in producing products, serving consumers, and achieving organizational goals (Wirawan [1]). Organizational culture is a system of shared beliefs and values in the organization and directs the behavior of its members. Every organization certainly carries out a program starting from the planning stage to evaluation [1]

Corporate culture, or also known as work culture, is the dominant values disseminated within the organization and is referred to as the work philosophy of employees. According to Moeljono [3], corporate culture refers to a system of shared meanings adopted by members that differentiate one organization from another. Therefore, it is not an exaggeration if Kreitner and Kinicki [4] define corporate culture as the glue of the organization through the values that are adhered to, symbolic tools, and social ideals to be achieved.

Meanwhile, Moeljono [3] clarifies by defining corporate culture as a system of shared values, beliefs, and habits in organizations that interact with formal structures to 
produce behavioral norms. It can also be interpreted that corporate culture is an information system to maintain and transmit knowledge, beliefs, myths, and behavior. Based on the explanation of the theory of organizational attitudes and culture, a basic understanding of attitudes to organizational culture can be drawn. This means that the concept of organizational culture becomes the object of attitude. The definition of attitude to organizational culture is the degree of positive or negative affection for organizational culture (in the form of a system of shared values, beliefs, and habits in organizations that interact with formal structures to produce behavioral norms).

According to McShane, Steve. L. \& Von Glinov, Marry Ann [5] the dimensions of organizational culture are:

a. Dimension of control culture

This culture assesses the role of senior executives to lead the organization. The aim is to keep everyone going one way and under control.

b. Dimension of work culture

This culture assesses individual and organizational performance and strives to achieve effectiveness and efficiency.

c. Dimension of relationship culture

This culture values the nature of affection and humanity. It grounds open communication, equity, and teamwork.

d. Dimension of responsive culture

This culture teaches to adjust to the external environment, being competitive, and realizing new opportunities.

Employee performance is a level of achievement for the implementation of certain tasks of an employee. Performance management is an overall activity carried out to improve the performance of an organization, including the performance of each individual and group in the organization. Performance is the work result in quality and quantity achieved by an employee in carrying out his duties following the responsibilities assigned to him (Mangkunegara [6]). According to Mathis [7], employee performance is the main factor that determines the success of an organization. Things that affect employee performance are ability, organizational support, and effort.

There are six indicators to measure individual employee performance (Bernardin in Robbins [8]), namely:

1. Quality

Quality is a level where the desired activity results are close to perfect. This means adjusting some ideal ways of performing activities, as well as the expected goals of the activity. The quality of work is measured by how much production per month within one year.

2. Quantity

Quantity is the work output expressed in terms such as the number of units or the number of activity cycles completed. For example, a quantity measured from the number of books produced in a year with a target set every month.

3. Punctuality

Punctuality is the level of activity completed at the beginning of the stated time, by maximizing the time available for other activities. Punctuality is measured from the tasks given to be done within a specified period (one month) and from the employees' perceptions of an activity that is completed from the start of the work to the end.

4. Effectiveness

Effectiveness is the level of use of organizational resources (manpower, money, technology, raw materials) which is maximized in order to increase the result of each unit in the use of resources. Effectiveness can be measured from the data on the amount of production done during one year and from the perceptions of employees in completing the tasks assigned by the organization.

5. Independence

Independence is the level of an employee who can carry out his work functions without asking for help and guidance from others. Independence can be measured from employees' perceptions of duties in performing their respective work functions according to their responsibilities.

6. Work Commitment

Work commitment is the level where employees have a commitment to the agency and employee responsibilities to the office. Work commitment can be measured by using employee perceptions in fostering relationships with agencies as well as employee responsibility and loyalty to the organization. Employee performance indicators according to Mathis [7] are as follows Quantity, Quality, Employee Reliability, Presence

Based on two opinions regarding indicators related to employee performance, the researcher can conclude that the employee performance indicators used are as follows.

1. Quality

Quality is a level where the desired activity results are close to perfect. This means adjusting some ideal ways of performing activities, as well as the expected goals of an activity. The quality of work is measured by how much production per month within one year.

2. Quantity

Quantity is the work output expressed in terms such as the number of units or the number of activity cycles completed. For example, a quantity measured from the number of books produced in a year with a target set every month.

3. Effectiveness

Effectiveness is the level of use of organizational resources (manpower, money, technology, raw materials) which is maximized in order to increase the result of each unit in the use of resources. Effectiveness can be measured from the data on the amount of production done during one year and from the perceptions of employees in completing the tasks assigned by the organization.

4. Employee Reliability

Employee reliability is the ability of employees to do their jobs without much supervision. Employee reliability 
includes consistency of performance and reliability in service, accurate, correct and precise.

The selection of performance indicators above combines the opinions of Mathis [7] and Bernadin and eliminates several other indicators. This aims to limit the scope of research and aims to identify problems faced by employees in achieving predetermined work targets.

\section{RESEARCH METHODS}

This research uses descriptive research type with a quantitative approach. Quantitative research methods, as stated by Sugiyono [9], namely: "research methods based on the philosophy of positivism, are used to examine specific populations or samples, data collection uses research instruments, data analysis is quantitative/ statistical, with the aim of testing hypotheses that have been set."

According to Sugiyono [9], the descriptive research method is research conducted to determine the value of the independent variable, either one or more (independent) variables without making comparisons, or connecting with other variables. Based on this theory, quantitative descriptive research is data obtained from a sample of the study population which is analyzed by the statistical method used.

Thus, the method used in this study is attempted to be able to reveal the phenomena that are studied systematically in order to obtain the truth of the problem under study, namely by looking at the position of the independent variables, the dependent variable, and how the relationship between them both.

To direct the discussion, the researcher uses the following operational variables:

1. Influence

Influence is a relationship that is mutually influencing, namely the organizational culture variable (the variable that affects) and the employee's performance as the (affected variable).

2. Organizational Culture

Organizational culture is the norms, values, assumptions, beliefs, philosophy, organizational habits, etc. developed for a long time by the founders, leaders, and members of the organization which are then socialized and taught to new members and applied in organizational activities so that they affect the pattern. thoughts, attitudes, and behavior of organizational members in producing products, serving consumers, and achieving organizational goals.

3. Performance

Performance is a result of work achieved by a person in carrying out the tasks assigned to him based on skill, experience, sincerity, and time.

The sample is a part or representative of the population under study. According to Sugiyono [9] in his book "Metode Penelitian Administrasi" states "the sample is part of the number and characteristics of the population".

Based on the description above, the sample of this study was 46 people who were only civil servants of Sumedang Selatan District Office, Sumedang Regency.

\section{RESULTS AND DISCUSSION}

The recapitulation of Organizational Culture (X) variables is as follows:

Table 1. The recapitulation of Organizational Culture (X)

\begin{tabular}{|c|c|c|}
\hline NUM. & TOTAL SCORE & \% \\
\hline 1. & 180 & 78,26 \\
\hline 2. & 180 & 78,26 \\
\hline 3. & 182 & 79,13 \\
\hline 4. & 179 & 77,83 \\
\hline 5. & 176 & 76,52 \\
\hline 6. & 184 & 80,00 \\
\hline 7. & 180 & 78,26 \\
\hline 8. & 182 & 79,13 \\
\hline 9. & 185 & 80,43 \\
\hline 10. & 177 & 76,96 \\
\hline 11. & 175 & 76,09 \\
\hline 12. & 175 & 76,09 \\
\hline 13. & 186 & 80,87 \\
\hline 14. & 177 & 76,96 \\
\hline 15. & 178 & 77,39 \\
\hline 16. & 176 & 76,52 \\
\hline 17. & 178 & 77,39 \\
\hline 18. & 177 & 76,96 \\
\hline 19. & 177 & 76,96 \\
\hline 20. & 178 & 77,39 \\
\hline & $\mathbf{3 5 8 2}$ & $\mathbf{7 7 , 8 7}$ \\
\hline
\end{tabular}

Based on the recapitulation table above, it can be seen that the highest percentage of research variables related to Organizational Culture $(\mathrm{X})$ is that related to providing compensation to employees who are expected to be given periodically, namely $80.87 \%$. Furthermore, the lowest percentage is related to employees being able to work fast and with high abilities of $76.09 \%$. This shows that employees may not be able to do work quickly and must master all fields because each employee also has different advantages and disadvantages. Then the next lowest percentage is related to the statement that employees must have reliable experience and ability of $76.09 \%$. Based on conditions in the field, it can be seen that not all employees have the same experience and abilities, because they also have different advantages and disadvantages in doing the work assigned by the organization.

Table 2. The recapitulation of Employee Performance (Y)

\begin{tabular}{|c|c|c|}
\hline NUM. & TOTAL SCORE & $\%$ \\
\hline 1. & 187 & 81,30 \\
\hline 2. & 176 & 76,52 \\
\hline 3. & 175 & 76,09 \\
\hline 4. & 178 & 77,39 \\
\hline 5. & 183 & 79,57 \\
\hline 6. & 172 & 74,78 \\
\hline 7. & 177 & 76,96 \\
\hline 8. & 171 & 74,35 \\
\hline 9. & 177 & 76,96 \\
\hline 10. & 179 & 77,83 \\
\hline 11. & 176 & 76,52 \\
\hline 12. & 176 & 76,52 \\
\hline 13. & 174 & 75,65 \\
\hline 14. & 174 & 75,65 \\
\hline 15. & 175 & 76,09 \\
\hline 16. & 179 & 77,83 \\
\hline 17. & 174 & 75,65 \\
\hline 18. & 177 & 76,96 \\
\hline 19. & 175 & 76,09 \\
\hline 20. & 173 & 75,22 \\
\hline & 3528 & 76,45 \\
\hline
\end{tabular}


The recapitulation of Employee Performance (Y) variables is as follows table 2. Based on the recapitulation table above, it can be seen that the highest percentage of research variables related to Employee Performance (X) is related to the success of employees if they are able to achieve targets, namely $81.30 \%$. Furthermore, the lowest percentage is related to employees leaving work according to the predetermined time which is $74.35 \%$. This shows that the employees have so far been less disciplined in their work, in this case most of the employees often come home from work not in accordance with the specified time to leave work.

Based on the Pearson correlation $r$ value, it is known that the $r$ value for the effects of Organizational Culture (X) on Employee Performance $(\mathrm{Y})$ is $0.713>r$ table 0.290 . So it can be concluded that there is an correlation between the variable Organizational Culture (X) on Employee Performance (Y).

Table 3. Correlation level

\begin{tabular}{|c|l|}
\hline Coefficient Interval & Correlation Level \\
\hline $0,00-0,199$ & Very Low \\
\hline $0,20-0,399$ & Low \\
\hline $0,40-0,599$ & Neutral \\
\hline $0,60-0,799$ & High \\
\hline $0,80-1,000$ & Very High \\
\hline
\end{tabular}

The Organizational Culture variable (X) has a high correlation with the Employee Performance variable (Y), this is because the results of the correlation test are in the value range $0.60-0.799$.

\section{CONCLUSION}

Based on the discussion and analysis regarding the effects of organizational culture on employee performance in Sumedang Selatan District Office, Sumedang Regency, the researchers made the following conclusions:

1. It can be seen that the highest percentage of research variables related to Organizational Culture $(\mathrm{X})$ is related to providing compensation to employees who are expected to be given periodically, namely $80.87 \%$. Furthermore, the lowest percentage is related to employees being able to work fast and with high abilities of $76.09 \%$. This shows that employees may not be able to do work quickly and must master all fields because each employee also has different advantages and disadvantages. Then the next lowest percentage is related to the statement that employees must have reliable experience and ability of $76.09 \%$. Based on conditions in the field, it can be seen that not all employees have the same experience and abilities, because they also have different advantages and disadvantages in doing the work assigned by the organization.

2. It can be seen that the highest percentage in research variables related to Employee Performance $(\mathrm{X})$ is related to the success of employees if they are able to achieve targets, namely $81.30 \%$. Furthermore, the lowest percentage is related to employees leaving work according to the predetermined time which is $74.35 \%$. This shows that the employees have so far been less disciplined in their work, in this case most of the employees often come home from work not in accordance with the specified time to leave work.

3. The correlation between organizational culture and employee performance in Sumedang Selatan District Office Sumedang Regency is at a high correlation level with a correlation coefficient of 0.713 .

4. The value of the effects of organizational culture on employee performance in Sumedang Selatan District Office Sumedang Regency is 50.8\%.

\section{Recommendations}

1. So that the organizational culture runs according to what is expected and in accordance with employee performance, the efforts that can be made to overcome these problems are: It is expected that the theories of public administration and public management can be used as a reference in the formulation of a public policy and improvements in terms of organizational culture and employee performance. A clear division of work, so that targets and their realization are achieved and do not cause miss-communication among employees. Practically from the results of this study can be valuable input for all parties who are directly involved in the activities of implementing an organizational culture and employee performance at the Sumedang Selatan District Office, Sumedang Regency.

2. In order to establish a good atmosphere at work, entertainment should be provided in the form of formal or informal activities, such as morning exercise. This can create better cooperation and relations among employees and between work units.

3. Increasing work discipline through leadership supervision is needed. So that it will be a motivation for employees who are still negligent in their work

4. To expedite work, it is better if it is supported by adequate facilities, infrastructure, training, and education for employees. They are able to support the improvement of employee performance.

5. The district head (camat) should always motivate employees when giving tasks and give them time according to the tasks appropriately. So that employees can complete their work quickly and on time.

\section{REFERENCES}

[1] Wirawan. 2007. Budaya dan iklim organisasi: Teori aplikasi dan penelitian. Jakarta: Salemba Empat.

[2] N. Karmila and Y. Suchyadi, "Supervisi Pendidikan Di Sekolah Alam Bogor," J. Pendidik. dan Pengajaran Guru Sekol. Dasar, vol. 03, pp. 31-33, 2020. 
[3] Moeljono, Djokosantoso. 2003. Beyond Leadership: 12 Konsep Kepemimpinan. Jakarta: PT Elex Media Komputindo, Kelompok Gramedia.

[4] Kreitner, Robert \& Kinicki, Angelo, 2003, Perilaku Organisasi, diterjemahkan : Erly Suandy, Salemba Empat, Yogyakarta

[5] McShane, Steve. L. \& Von Glinov, Marry Ann. 2005. Organizationnal Behavior. Tirth Edition. Mc Graw-Hill.

[6] Mangkunegara, 2004, Manajemen Sumber Daya Manusia Perusahaan, PT remaja rosdakarya, Bandung.

[7] Mathis, R.L. \& J.H. Jackson. 2006. HumanResourceManagement:ManajemenSumberDay aManusia. Terjemahan Dian Angelia. Jakarta: Salemba Empat.

[8] Robbins, P. Stephen. 2002. Perilaku Organisasi: Konsep Kontroversi, Aplikasi. Jilid I Terjemahan.,PT. Indeks Kelompok Gramedia, Jakarta, 2002.

[9] Sugiyono.2004. Metode Penelitian Administrasi(ed.5). Bandung : CV. Alfabeta 